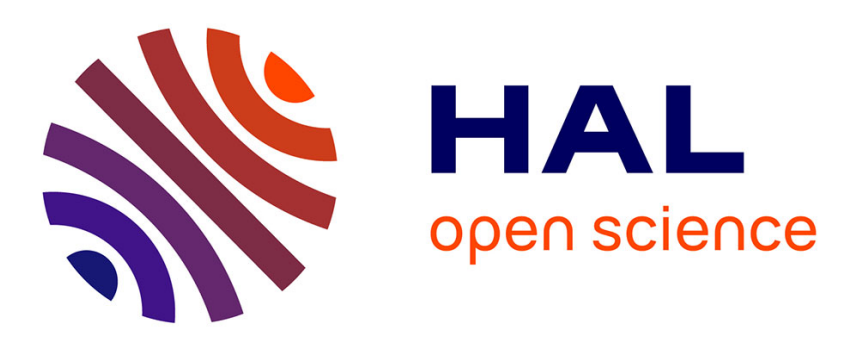

\title{
Characteristics of Traditional Farm Equipment in Korea from the Viewpoint of TRIZ's Invention Principle
}

\author{
Sehoon Cho
}

\section{To cite this version:}

Sehoon Cho. Characteristics of Traditional Farm Equipment in Korea from the Viewpoint of TRIZ's Invention Principle. 19th International TRIZ Future Conference (TFC), Oct 2019, Marrakesh, Morocco. pp.458-471, 10.1007/978-3-030-32497-1_36. hal-02905558

\section{HAL Id: hal-02905558 \\ https://hal.inria.fr/hal-02905558}

Submitted on 23 Jul 2020

HAL is a multi-disciplinary open access archive for the deposit and dissemination of scientific research documents, whether they are published or not. The documents may come from teaching and research institutions in France or abroad, or from public or private research centers.
L'archive ouverte pluridisciplinaire HAL, est destinée au dépôt et à la diffusion de documents scientifiques de niveau recherche, publiés ou non, émanant des établissements d'enseignement et de recherche français ou étrangers, des laboratoires publics ou privés. 


\title{
Characteristics of traditional farm equipment in Korea from the viewpoint of TRIZ's invention principle
}

\author{
Sehoon $\mathrm{CHO}^{1[82-10-2712-7560]}$ \\ ${ }^{1}$ Hanwha Precision Machinery, Seongnam-Si, Gyeong-Do, South Korea \\ Ph.D. student at Korea Polytechnic University \\ sehoon.cho@hanwha.com, sh68.cho@gmail.com
}

\begin{abstract}
Agriculture is an industry based on human history, as anyone can easily recognize. There are various tools and cultivation methods for unique agriculture in many countries of the world. And such farming methods and tools used have evolved over time. It is accepted by the general public as an understanding of the uniqueness rather than an attempt to analyze which tools are relatively more efficient.

Today, a variety of traditional farm equipment in each country is being used in part. Where large-scale factory farming uses modernized equipment. In this study, I briefly analyzed how the characteristics of agricultural equipments used in rural villages are related to TRIZ 's inventive principle and resource utilization. The inventive principles of TRIZ are easily found in Korean farm equipment. Some tools are understood as aspects of modern science or sports science.

Over the past several hundred years, most farm equipment has been completed with materials and methods to create optimized structures, methods and tools. It has efficiency and environmental friendliness. Given the environmental conditions, the use of local materials and experience-based wisdom is dissolved.

Some tools also have semantic implications for environmental issues, cyclical economies, and sustainability that have emerged as problems in recent years. Therefore, it is important to develop new complex systems or to study equipment with advanced functions. However, by using good examples already existing, I would like to get hints as another alternative to various problems arising from the recent industries of machinery, electronics, computers, petrochemicals, and so on.
\end{abstract}

Keywords: Cyclical economies; Sustainability; Korea; Traditional farm equipment; TRIZ; Invention principle; Resource analysis; Appropriate Technology 


\section{Introduction}

\subsection{History and Agriculture in Korea}

Korea usually has a history of 5000 years. It is presumed that many countries have historically developed into cultivated forms gradually as they settled around the river in nomadic life. Korea was estimated to have started full-scale farming since 3000 BC. However, ancient rice seeds found in Korean Shinbuk in 2003 were estimated to be about 15,000 years ago and recognized by the World Association. It is estimated that Korea has a very long agricultural culture all over the world.

Therefore, it is a nation that mainly engages in agriculture, and it has been various for a long time and various crops and food culture accordingly. It was in the early 1960s that the modernization of Korea's agricultural environment began to take full advantage of its power. Prior to that, agriculture was mainly farming with manpower, accumulation and natural environment. Nowadays, agriculture is applied to simple agricultural agriculture using advanced technology such as factory farming facility, hydroponics using LED, facility management using IoT technology, and spraying pesticide with drone. Mechanization Despite the computerized changes, farm tools that have been used for a long time are now being partially used. In this paper, we try to share some meaning of traditional agricultural equipments which are used now.

\subsection{Korea's Natural Environment and Agriculture}

Korea has four seasons of weather change in one year. This environment has played a very large role in agriculture. It can be divided into the farming season and the resting season depending on the weather. Farming season is a very busy time when the actual things necessary for farming take place in farmland. On the contrary, the rest period corresponds to a kind of preparatory period that takes place inside the house with little occurrence of farmland outside the house. There are traditions in which land is sown, sown and cultivated and harvesting work in cooperation with neighbors in a short period of time because the tasks to be carried out by the step of farming are decided. Some work alone, but many farmers are made to work as a group.

Most of the rest days are from the time when the harvest of late autumn ends, the temperature falls below freezing, the time when the cultivated area becomes frozen, and the beginning of the next spring, when the ice begins to melt. During this period, various preparations are made for practical farming. They will do follow-up work on harvested crops, and make consumable work tools that are often used in farming. It is the time when crafts and tools made of various straws are made using straws to make strings that are used as versatile strings. It is also the season for repairing the tools used in the farming season. To repair the farm equipment, we prepare and process the tree, or repair the necessary equipment in the blacksmith shop. 


\subsection{Challenges of Current Agriculture in Korea}

Through a very short period of 20 to 30 years, Korea has changed from traditional farming to mechanized farming. After the Korean War, agricultural productivity was so low that it concentrated on increasing food production per unit area. As a result, food problems and productivity were solved, but the soil was acidified by massive use of chemical fertilizers, pesticides and chemicals, and many pollutants were generated in rivers and land.

Various efforts have been made to restore, but the recovery of nature is slower than expected. The rapid aging of the population is also recognized as a new problem. The relationship with neighbors is loosening by working with automated agricultural machinery without the help of neighbors. In front of these new challenges, we will learn the wisdom of the ancestors included in traditional farm equipment to gain wisdom in solving current problems.

\section{Characteristics of major agricultural equipment in Korea}

We have extracted some features of Korean farm equipment from TRIZ 's problem environment analysis aspect with characteristics of 130 different kinds of farm equipment in Korea, how to use it, and natural environment.

\subsection{Village Cooperative Agriculture}

In a situation where the changes in the four seasons of the year have to be met, farmers often cooperate in farming rather than individual farming. There are a lot of farm equipment that at least two people should join together in a variety of farm equipment, and the labor cost has developed much by region. There were a lot of cases where we worked together singing along with farming days that could be boring in wide fields. It is a sort of community structure, but it is a group that has a horizontal relationship and cooperates with each other. It is called 'Dure'. Similar to Kibbutz, a collective farming community in Israel, all of Korea has a different form of private property base. The workpieces transmitted by word of mouth were shared through festivals and various festivals. Several people have good structural characteristics to work together.

\subsection{Agricultural Equipment Material and Circulation Economic Characteristics}

Most of the farm equipment used very common materials that can be easily found around. As a result of rice farming, straw has been used for a variety of purposes. (Fig. 1). They used various properties of the straw. Straw is also a by-product of producing food. The byproducts become the key material for tools to store and transport food. 

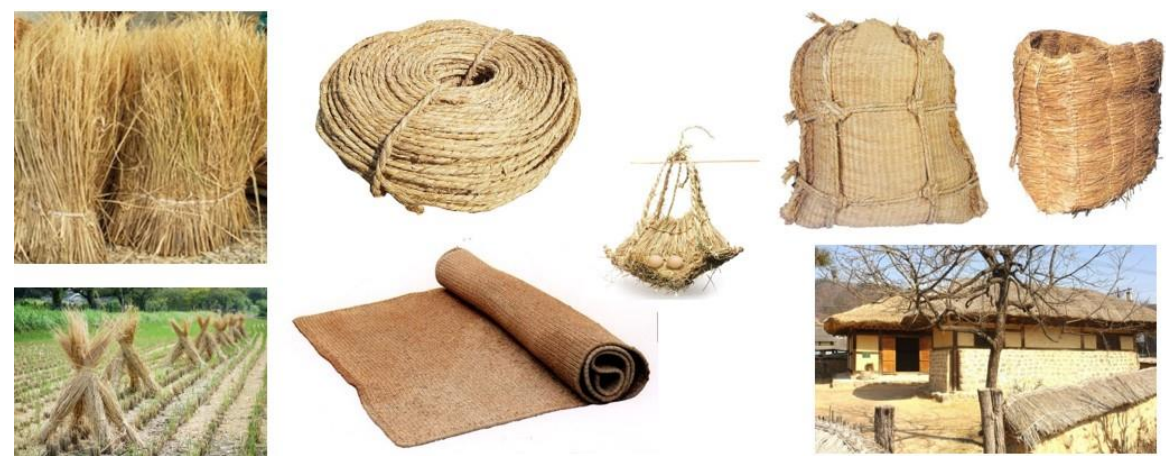

Fig. 1. Straw cases

It is characterized by $100 \%$ circulation when the life span of the used farm equipment or the agricultural equipment is exhausted. Most are composted or become heating firewood. In addition, partial repair is easy for each component. Trees or straw are also used as additional fertilizer. On the contrary, today's petrochemical strings are mostly not recycled after use, and they cause soil and river pollution.
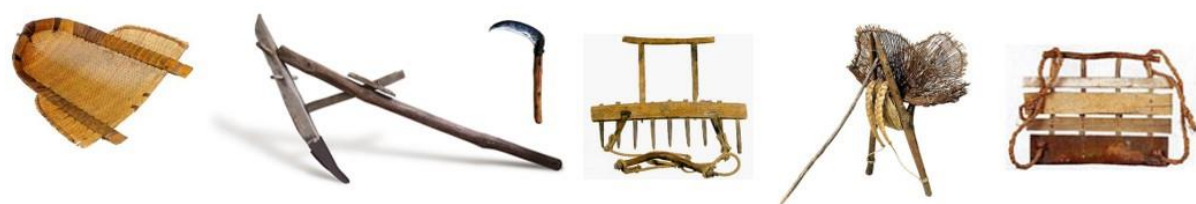

Fig. 2. A variety of farm equipment in Korea

All components are made of wood or straw except for the iron-made part made of blacksmith. This can be interpreted as a dimension that utilizes various derivative resources from the viewpoint of 'resource analysis'.

\subsection{Systematic classification and various kinds}

There are more than 130 farm equipment in Korea. Table 1 below shows the types and types of farm equipment classified into 16 stages based on the timing and function of farming. It is estimated that more than 130 kinds of agricultural equipments did not appear at any particular time but gradually increased according to the working environment for a long time. Korea is known as an agricultural country, although the three sides are made up of sea. Historically, many kings have been noted for their success in agriculture, water management for agriculture, interest in rivers, reservoirs and so on. It can be considered that there is an attempt to improve the systematic farm equipment in the country if it is deduced that the national history document contains a lot of records about the farm equipment. 
Table 1. Korea's farming season and farm equipment [2]

\begin{tabular}{|c|c|c|c|}
\hline Procedure & Function & Name of farm equipment & Amount \\
\hline 1 & Digging & 따비, 쟁기, 극젱이, 괭이, 가래, 삽 & 6 \\
\hline 2 & Soil refinement & 써레, 쇠스랑, 곰방메, 번지, 나래, 고무래, 발번지, 통번지, 발나래 & 9 \\
\hline 3 & $\begin{array}{l}\text { Compost } \\
\text { movement }\end{array}$ & 장군, 새갓통, 귀때동이, 거름통, 삼태기, 거름대 & 6 \\
\hline 4 & Seeding & 고써레, 드베, 파종기, 씨송곳, 씨망태, 씨삼태, 종다래끼, 끙게, 실번지, 궁글대 & 10 \\
\hline 5 & Weed removal & 호미, 밀낫, 칼자매, 매번지, 보토괭이, 제초기 & 6 \\
\hline 6 & Water supply & 두레, 맞두레, 용두레, 무자위, 물풍구, 살포 & 6 \\
\hline 7 & Harvest & 낫, 전지, 도리깨, 탯돌, 개상, 홀태, 그네, 탈곡기, 삼괭이 & 9 \\
\hline 8 & Dry & 얼루기, 멍석, 도래방석, 발, 거적, 채반 & 6 \\
\hline 9 & $\begin{array}{l}\text { Wheat } \\
\text { extraction }\end{array}$ & 부뚜, 듸림부채, 풍구, 바람개비, 키, 이남박, 체 & 7 \\
\hline 10 & Grain storage & 독, 나락뒤주, 쌀뒤주, 통가리, 섬, 가마니, 중태, 멱서리, 뒤웅박, 씨주머니 & 10 \\
\hline 11 & Grain grinding & 절구, 디딜방아, 물방아, 물레방아, 돌확, 맷돌, 매통, 토매, 연자매, 기름틀, 국수틀, 물절구, 안반 & 13 \\
\hline 12 & Carry & $\begin{array}{l}\text { 지게, 발채, 들 것, 망태기, 소쿠리, 광주리, 바구니, 다래끼, 멱둥구미, 길마, 거지게, 걸채, 옹구, 발 } \\
\text { 구, 썰매, 수레, 달구지 }\end{array}$ & 17 \\
\hline 13 & Livestock tools & 구유, 여물바가지, 쇠죽쇠스랑, 작두, 덕석, 부리망, 어리, 둥우리 & 8 \\
\hline 14 & $\begin{array}{l}\text { Straw } \\
\text { application }\end{array}$ & 짚추리개, 자새, 돌물레, 섬틀, 가마니틀, 자리틀, 새끼틀 & 7 \\
\hline 15 & $\begin{array}{l}\text { Fabric } \\
\text { manufacturing }\end{array}$ & 씨아, 물레, 돌꼇, 날틀, 베틀 & 5 \\
\hline 16 & Other & 갈퀴, 넉가래, 함지, 메, 도끼, 까뀌, 톱, 반달낫, 도롱이, 태, 덫 & 11 \\
\hline \multicolumn{3}{|r|}{ Total Amount } & 136 \\
\hline
\end{tabular}

\subsection{Breakdown of Structure and Name of Farm Equipment}

Most of the farm equipment was improved and optimized according to the purpose of use. It can be seen that the structural features, functions and performance have become clear during the optimization process. As an example, a sickle cutting a tree or weed is a very simple tool, but its name is clearly distinguished as shown in the figure below.

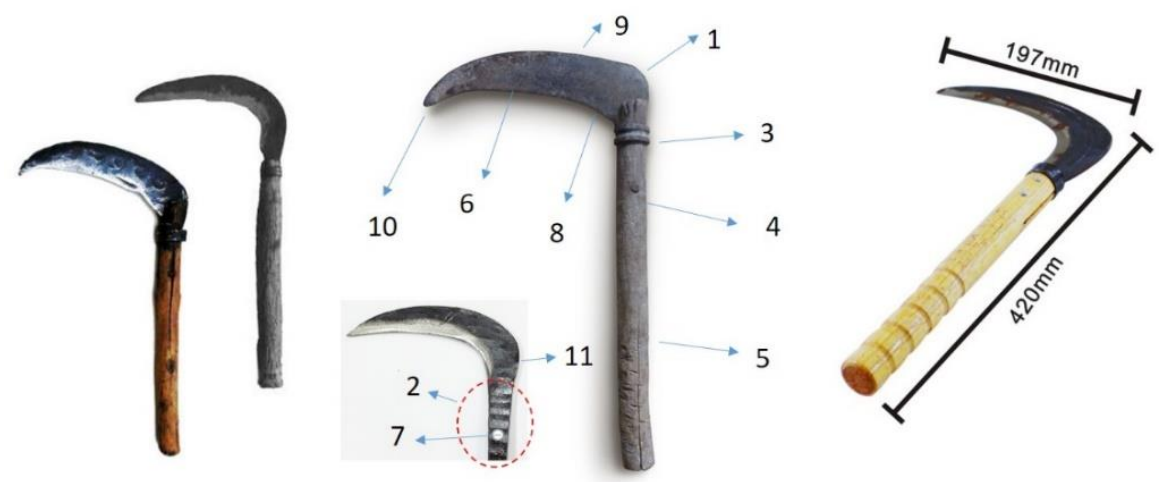

Fig. 3. Structure and name of Korean sickle [3] 
It is a technical system that a simple tool has different names depending on structure, shape and function. In other words, it is a simple but seemingly simple technology system. It's as if each component of a complex mechanical system has its own manufacturing method and name. Each tool has its own name and the materials and manufacturing methods used in its manufacture. There is a whole name, but having a unique name for the parts that make up the whole means that there is a unique function.

\subsection{Manufacturing locally: Appropriate technology}

Most farm equipment is made in the local area, that is, the area where it is used. Strictly speaking, it was made in a home that needs it. It is a practical form of proper technique. Made with materials that are very easily available in your area. Most of the farmers at the time were able to make most of the farm equipment with only basic basic tools. It was made with tools that were readily available at village level. In the case of iron farming equipment, it is usually purchased through a market that is held regularly by city, or it is repaired in a blacksmith shop in winter. They have the same form, but they have made farm equipment with materials that are produced or naturally produced in the area.

\subsection{Harmonization with Super Systems: Resource Analysis}

It is in harmony with the operation of the human body, which is an upper system. The upper system has characteristics that are optimized to the characteristics of the upper system from the point of view of interaction with the human farm equipment. Farmers using livestock have also developed a variety of additional tools to keep the livestock constantly focused on their work, rather than simply using the power of livestock. Livestock, such as cattle, have the highest value of property in most households, and work has been done to take care of their health. In addition to farming equipment, it is also shown in the construction of trees along the shape of the surface of rocks and stones when pillars are erected on the foundation stone of Korean houses. The Ondol system, which exists only in Korea, is a heating system in which the properties of stone and soil and aerodynamics are studied in harmony.
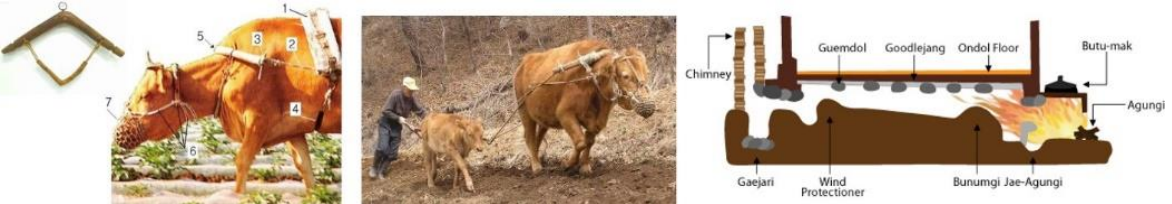

Fig. 4. Analyze and harmonize top system resources [4,6]

In many cases, it is assumed that farm equipment has been improved in such a way as to study and use the properties of the natural state or the material before it is artificially processed. 


\section{Korea's representative traditional farm equipment}

There are about 130 kinds of traditional farm equipment in Korea, but among them, only some of the farm equipment that have been used only in Korea until now and their characteristics are examined. Most of the farm equipment was visible in the museum. Most of the farmers have experience in using the farm, and this is the TRIZ theory. I will review why TRIZ has 40 generic inventions found in their farm equipment (technical systems), and why farming tools are virtually unchanged in form and usage for a long time.

\subsection{Case: Homi}

Homi was a traditional farming tool in Korea, but now it is known as a gardening tool sold by Amazon.

\subsubsection{History and Uses of Homi}

The shape of Homi varies slightly depending on the farming environment and region of Korea (Figure 5). The shape of the work depends on the soil condition in each area. Depending on the type of weeds, the depth is different and the hardness of the soil varies depending on the soil. As a result, the shape of the body was slightly modified according to the problem, and the angle and length of the blade, the length of the handle, and the shape of the side were changed. Also, a customized order can be made in the blacksmith individually. This can determine the type of detail of the Homi by the user's experience.

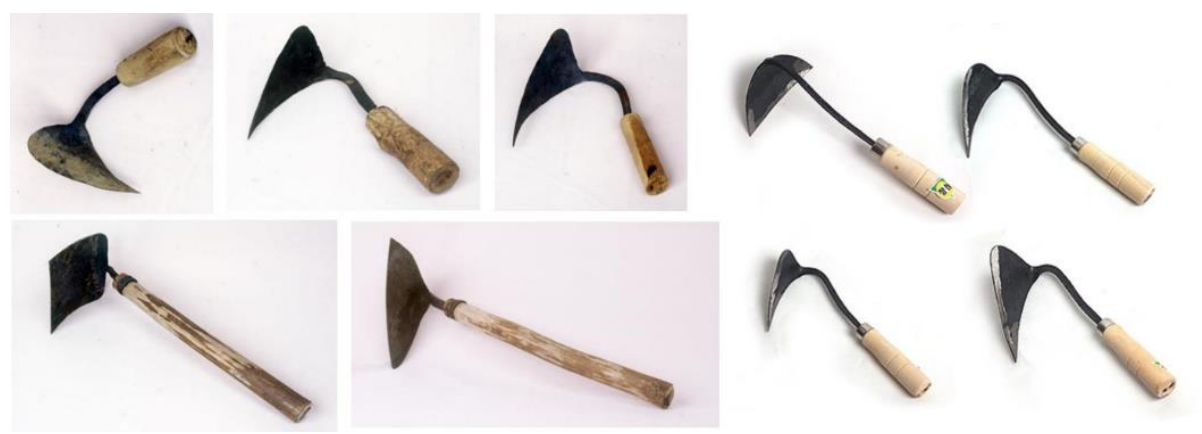

Fig. 5. Various aspects of Homi [5]

\subsubsection{Structure and function of Homi}

Homi is mainly used by people to sit in a sitting position and to decorate their hands or garden. After sitting in the space to work, various tasks are possible. Depending on the proficiency level, the time and type of work will also vary.

Figure 6 shows the functional relationship when holding Homi by hand and pulling toward the body. Homi uses the power of the hands and arms of the human body to 
work with structures optimized for digging the soil or selectively removing or removing weeds. The pulling force will cause the lower part of the body to fall into the ground.
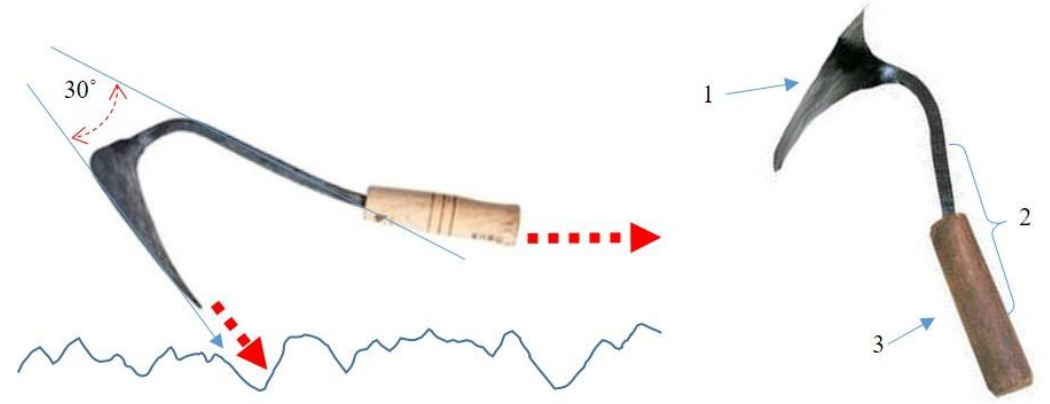

Fig. 6. Structure and function of Homi

Homi also has a versatile function in one shape. It can be used in a variety of times and places that usually do simple work in the field, such as the ability to scratch the earth or collect the soil, to move the soil, to cut off the roots of the weeds, to dig the ground. In some cases, the handle 3 may be wrapped with a cord so that the hand holding force is evident.

Though 1000 years later, the structure of Homi is still used. It is one sample of IFR of hand tool. It is still being sold as a best-selling product on Amazon (Figure 7).
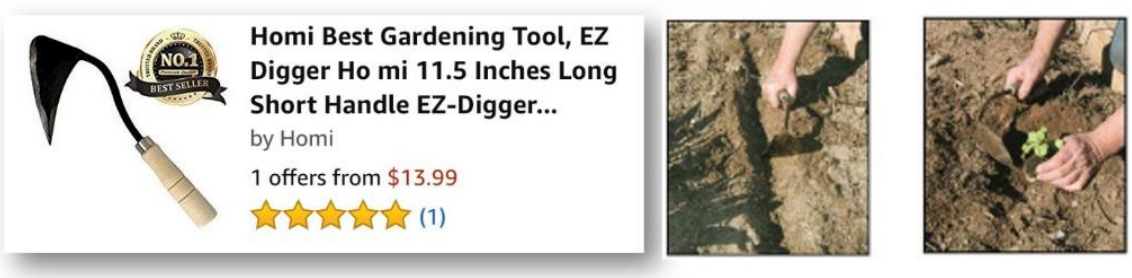

Fig. 7. Homi currently on the Internet [5]

There is a review of users who purchased Homi using Amazon, which expressed satisfaction with "I can not find a 30-degree curved day anywhere in the US" or "How did you make your garden before writing Homi?" [5]

\subsubsection{Founding principles of invention}

It can be found that at least five inventive principles are applied to Homi.

a. 3) Local quality - Different features are unique to each function

b. 6) Universality - The body made of iron contains various functions

c. 16) Partial or excessive action - When pushing in the handle, it burns quickly and pushes it in.

d. 25) Self-service - Bend the handle so that the handle does not come off the body.

e. 40) Composite materials - Handles are made of wood and wrapped around the surface with rope 


\subsection{Case: Chige}

There are several required functions and constraints to move things in the rural environment of Korea. A given situation can simply be set to Task. And the result of continuous improvement to solve such a problem situation can be interpreted as the current state. On the other hand, it is also possible that the current shape of the biceps has been created in a shorter period of time. It is structurally meaningful in interaction with components.

\subsubsection{Necessity and Required Function}

The necessity of the first Chige is not known, but based on actual experience, it can be demanded that the problem situation when Chige is not used is reverse estimated and summarized below.

a. Carry heavy objects or bulky luggage (carry as much luggage as possible)

b. Carrying baggage to limited places such as narrow roads and mountain roads (acceptance of upper system limit)

c. Shielding or minimizing the constraints of action on the move (not dangerous)

d. Easy to travel long distance

\subsubsection{Chige's history and change}

Korea's Chige has maintained its shape for hundreds of years without substantial change. The figure below (Figure 8) shows that Chige in the picture of a painter several hundred years ago is the same as that of the last 30-70 years ago.

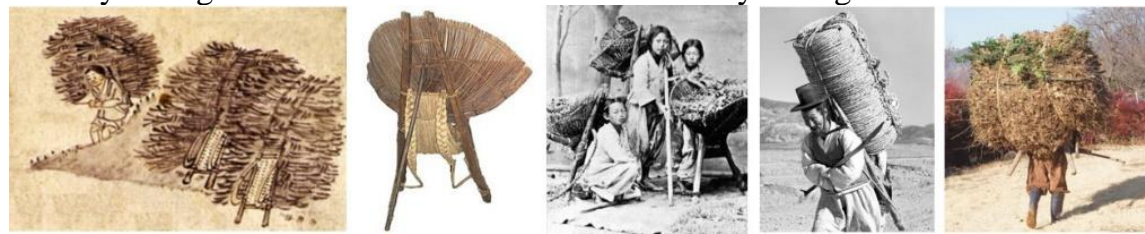

Fig. 8. Past and recent Chige's appearance

Usually, it is difficult to use wheeled transport tools if you need to carry your luggage to a narrow, hilly or narrow place. In the same situation, Chige is still being used with its traditional structure. The form remains intact. During the Korean War, Chige was used to create a special unit to move military supplies to the mountains.

\subsubsection{Structural features of Chige}

As mentioned above, the name of Chige can be divided into 15 kinds as well as the features of traditional Korean farming tools. And the location of each component is located where it interacts with the human body skeleton. Most houses in rural areas in Korea had Chige, which is the same shape but different in size. The reason is because the body size of the person using it is different. Patient height, shoulder width, and hip position are the main variables. Figure 9 compares the general structure of the body and the structure of Chige corresponding to the skeleton. 
Chige has a form A so that the center of gravity is well caught when a heavy load or a bulky thing is carried. When hanging the Chige on the shoulder, the lower structure is arranged outward so that it is not caught on the legs. After the load is loaded on the Chige, it has a structure that supports it so that it does not move toward the head. In other words, it has been manufactured to fit well with the interaction position considering the structure and function of the body which uses the characteristics of human body well. There are a variety of things that you can carry on your Chige. You have additional options for when you need to move grain or small objects. 'Baroguri (15) can be temporarily connected to each structure $(1,6)$ while spreading to be well placed in the base structure of Chige.
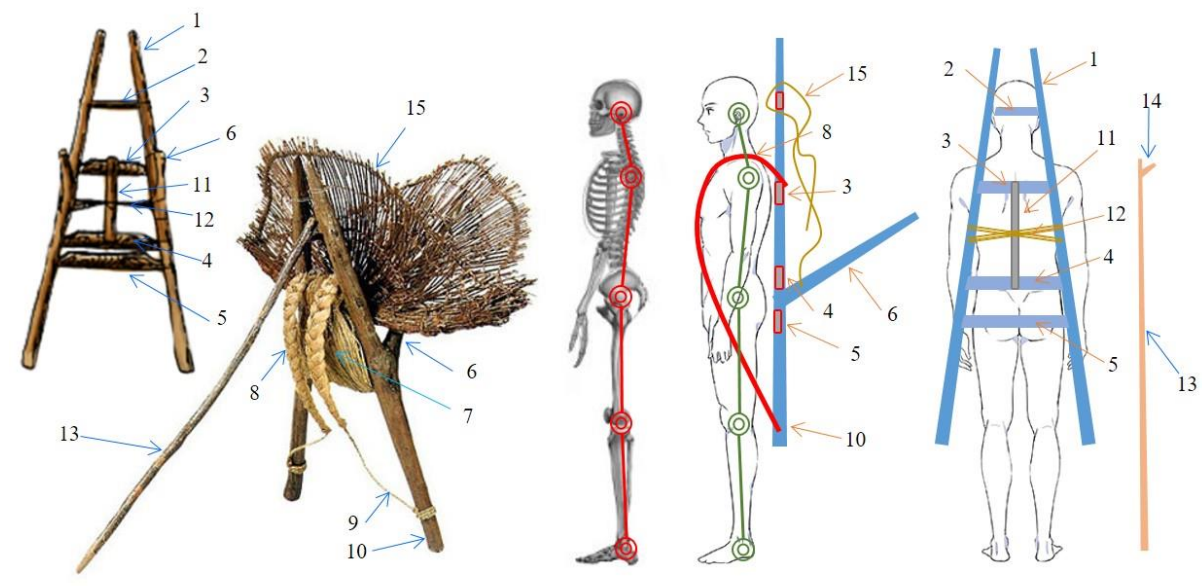

Fig. 9. Chige's structural features and human skeleton

\subsubsection{Mechanism of Load Transport Using Chige}

In Fig. 10, if the load is loaded on the Chige, it is fixed with the strap (15). It is possible to balance the erected Chige and stand it up with the support rod 13 slightly inclined. At this point, the user will remember the tilted level of Chige and (b) maintain the angle when he tries to stand up against Chige on his shoulder. If you shake a little, you will know how much strength it supports. These interactions are taught in principle and practice at the point of use of Chige. Therefore, parents should check whether they fit the body before making Chige for children or using Chige.

a. Chige depends on the size of the body, weight support position is different.

b. Depending on the weight of the body, the angle of the body and the angle of the Chige are different.

c. Structural features that maximize human body function 


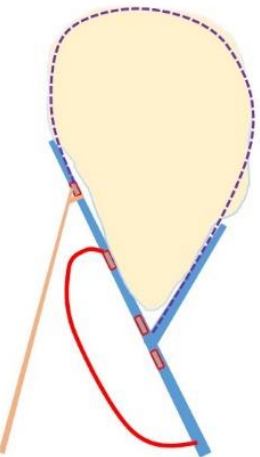

(a)

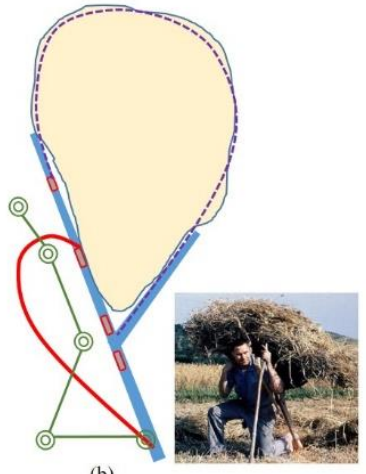

(b)

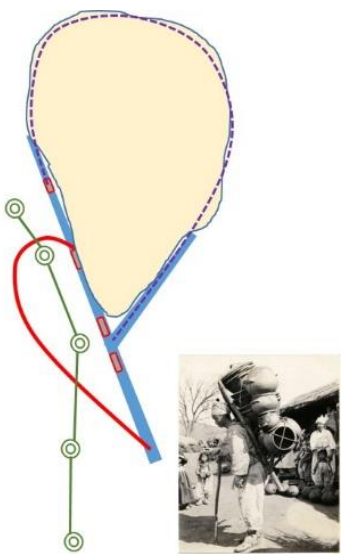

(c)

Fig. 10. Preparing for change and movement of the center of gravity

\subsubsection{Problems and solutions of Chige's manufacturing process}

All the materials that make up Chige use local materials that are available to anyone in rural Korea. Most farmers directly manufacture. Manufacturing takes into account the physical condition of the person using it.

In the structure of Chige, the place where weight is most applied corresponds to branch (6). This weakness affects the bulk or weight of the load that can be loaded. Therefore, when choosing materials to support weight, we make a tree with branches that are angled about 60 degrees from the main stem of the tree. Trees with bold branches have very rigid structural features when they are built. Cut the tree beforehand because the tree is distorted during the drying process. After the wood has been partially dried, it will become less warped after production
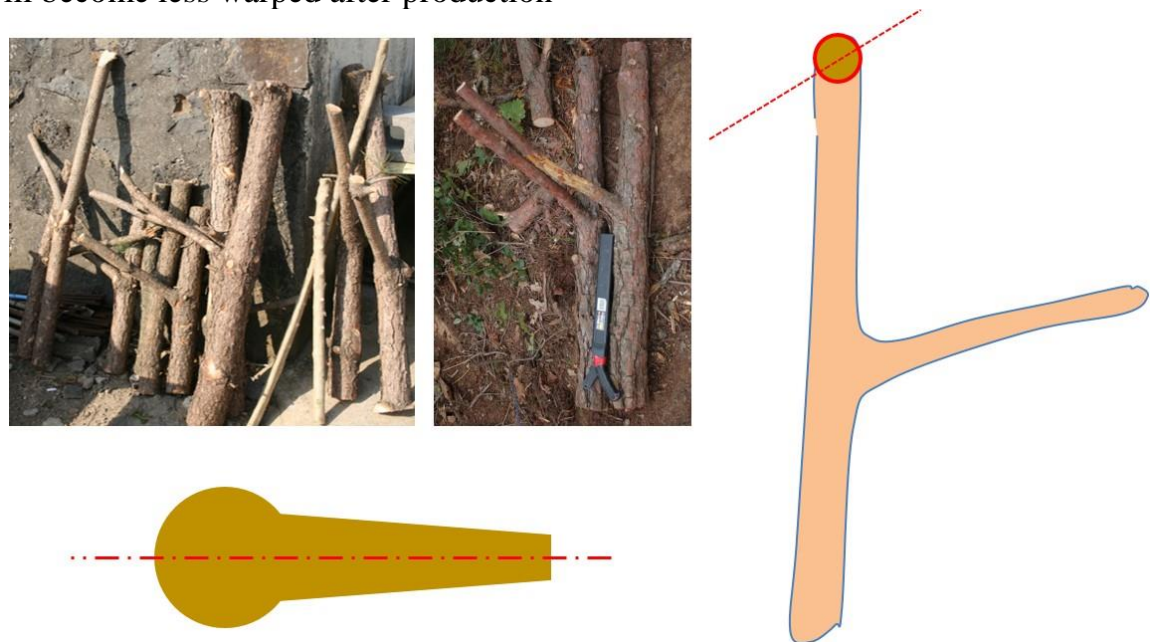

Fig. 11. Wood preparation for Chige manufacturing 
Chige is an unbalanced structure from the side, but from the front, both sides need to be balanced in terms of structure, weight and stiffness. As shown above, it is difficult to obtain trees with the same structure and rigidity in nature. Most of the fixtures were somewhat imbalanced. In order to solve this problem, it is possible to make a tree by dividing the tree which is twice as thick as the tree which is necessary for making the final load. Especially in this case, the wood is cut and dried naturally because there is a possibility of distortion after production.

\subsubsection{Founding principles of invention}

It can be seen that at least five inventive principles apply.

a. 12) Equipotentiality - Raise a certain height from the ground to move heavy loads, and then make it easier to move.

b. 9) Preliminary anti-action - Check the center of gravity before carrying the baggage.

c. 2) Extraction - Cut out a part of the tree with branches.

d. 27) Cheap short-living objects - Use straw to easily replace major parts.

e. 24) Intermediary - Place a straw cushion on the frame of the frame and on the back of the person and directly touching the buttocks to make them hard.

In addition, the harmony with the upper system of the human body is outstanding.

\subsection{Case: Treadmill}

The basic principle of treadmill is known to come from China, but we do not know the exact time. However, the form and use of Treadmill in other countries have changed a lot. Since its introduction, it has been improved to Korean type according to the Korean environment.

\subsubsection{Basic Structure of Treadmill}

Figure 12 shows the general form of Korean Treadmill.

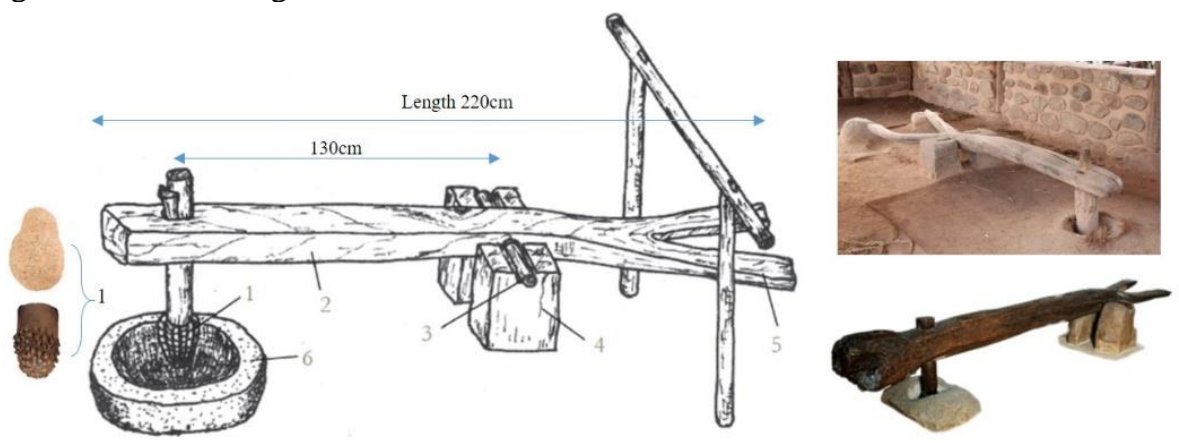

Fig. 12. Basic structure of treadmill [7, 9]

The biggest change is to use a tree with two branches so that both of them weigh the treadmill. The material is made of wood and stone. The end (1) of the armor is made of iron. 
The end portion 1 may be replaced depending on the object to be ground. The container 6 containing the grain is mostly made of stone and the portion 4 receiving the rotation and the load of the body 2 is also formed by grooving the stone. Hang the strap from the transverse support or ceiling to support it, as the person may lose balance during operation. You can run the grain through your treadmill alone, but you can work faster if you have 2 or 3 people together. Of course, there is a song to sing while working with a treadmill.

\subsubsection{Application and Change of Treadmill}

Figure 13 shows the shape of the change in force that drives the treadmill. Currently, there is little threshing or crushing using these facilities. But it is an example of using water instead of manpower. Of course, in countries with windy winds, there is a structure connected to windmills.
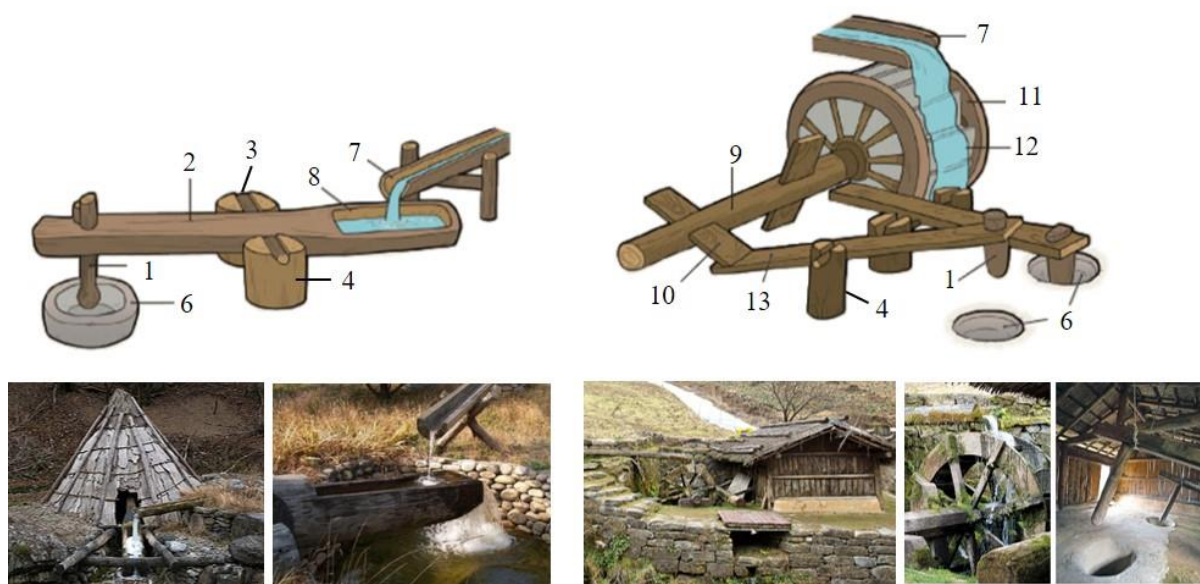

Fig. 13. Treadmill action by various hydraulic power[8]

\subsubsection{Characteristics of Korean Treadmill and Principle of Invention}

At least five inventive principles apply to treadmill.

a. 1) Segmentation - Allows two people to gain weight in the way a person applies weight

b. 4) Asymmetry - Asymmetric structure

c. 8) Counterweight - Counterweight - Counterweight is released after weight is applied.

d. 19) Periodic action - Periodic action to release and release weight

e. 25) Self-service - The bottom of the container is narrowed so that the grain is lowered by self weight in the container.

f. 3) Local quality - The end of the arm that is easy to damage is made of stone or iron, so it is not easily worn. 


\section{Conclusions}

Researching traditional farm tools and various life tools will solve various problems and see optimized results. The methodology of TRIZ[1] is a problem solving methodology which is learned from the examination of the patent literature. Especially, three kinds of agricultural equipments introduced are basically found that five or more inventive principles are found, and it can be seen that the life span of the technical system is long by applying various inventive principles.

This study is similar, but the other is to get a clue to solve present and future problems with real data. TRIZ has derived the methodology from a number of patents by Alschuller, which has been around for almost 50 years, but is still very useful. This is a small attempt, but if you study systematically more traditional farm equipment or systems, I think there is a possibility to find clues to new international issues such as cyclical economy and appropriate technology. It is similar to the fact that we are getting a clue to many technical principles and problem solving in nature.

Although some of the representative ones have been roughly reviewed, systematic research on more can lead to a more desirable solution in which one solution is used rather than a temporary one, rather than a longer one.

\section{References}

1. Altshuller, G., The Innovation Algorithm: TRIZ, Systematic Innovation and Technical Creativity, Worchester, MA, 1999

2. Korean Society of Agricultural Machinery(KSAM), Korean Farm Equipment Book, 2001

3. Study on the Form and Principle of Traditional Sickle, KIM Hyogyong. Folklore Studies 40, pp 151 187, 2017. 6

4. https://ko.wikipedia.org/wiki/온돌

5. https://www.amazon.com/Hand-Ho-Mi-Digger-Inches-D9841-x/dp/B0091UPBDQ

6. https://m.blog.naver.com/12sungbok/40114513330

7. http://vsm.kisti.re.kr/agri/v-show/object/didil-1.htm

8. Yong Yong Yoon, National Science Museum

9. http://www.doopedia.co.kr 